\title{
THE ROLE OF VIRTUAL SPACE IN ENSURING 'FAIR ACCESS' TO BANKING SERVICES - RESULTS OF EMPIRICAL RESEARCH CONDUCTED IN THE POLISH SME SECTOR
}

\author{
Marek Szczepaniec $^{1}$ (D), Tomasz Jurkiewicz ${ }^{2}$ (D) \\ ${ }^{1}$ Faculty of Economics, University of Gdańsk \\ Armii Krajowej 119/121, 81-824 Sopot: Poland \\ marek.szczepaniec@ug.edu.pl \\ ${ }^{2}$ Faculty of Management, University of Gdańsk \\ Armii Krajowej 101, 81-824 Sopot: Poland \\ tomasz.jurkiewicz@ug.edu.pl
}

\begin{abstract}
The aim of this article is to present results of long-term empirical research on the changing behavior of micro, small and medium-sized enterprises (SMEs) in Poland in the context of spatial exclusion and spatial 'justice'. Between 2007 and 2015, the authors conducted cyclical research on the financial behavior of SMEs in Poland on large samples. The scope of research on traditional and virtual space covered mainly: the criteria for selecting a bank for current service and the use of various banking services in particular distribution channels. In the researched period, the percentage of indications to convenient location as the most important factor for selecting a bank dropped from $29 \%$ to $16 \%$. In the entire period under research, the highest percentage of indications to convenient location as the most important factor for selecting a bank was recorded in the micro enterprises sector. The percentage of entrepreneurs' indications of fees and commissions as the most important factor in choosing a bank increased from $28 \%$ to $36 \%$. Price parameters became the most important factor of bank selection in the SME sector. Virtual space was used primarily to distribute less complex banking services (checking the account balance and viewing the history of operations on the account, as well as to make transfers). In the case of more complex products, such as deposits or loans, traditional banking branches were preferred. In contrast to the results of the American research (Degryse \& Ongena, 2002), in Poland there was no impact of the distance between the company and the bank branch on the loan utilization rates and the loan refusal rates. The research has shown that the virtual space equalizes the opportunities, facilitates business operations, contributes to a drop in prices and improvement in quality of the offered products and services, and renders the access to products and services fairer.
\end{abstract}

Keywords: fair access, internet banking, SME, spatial justice, traditional banking, virtual space.

\section{Introduction}

Not until 30 years ago, the location was one of the key success factors in business activity. Enterprises operating in large agglomerations, located close to markets and having access to various services supporting business activity, had an unquestionable advantage over entities located in peripheral areas. Thus, we could speak of a quasi-spatial injustice. It was expressed, among oth- 
ers, by spatial sorting of enterprises, e.g. offering financial services on worse terms to companies located at a greater distance from bank branches or even denying access to credit.

The situation began to change when the World Wide Web appeared and started developing. Due to the Internet, the role of traditional space began to diminish, and the role of virtual space quickly grew. Network access was sufficient and the company could already operate not only on the local or national market, but also on the international one. Business support services, including financial services, have become more accessible. A company owner, who had previously wasted a lot of time on getting to the branch and dealing with basic banking matters (checking the account balance and history of operations, making transfers, etc.) suddenly gained immediate and uninterrupted (24/7) access to his account.

The virtual space has created a level playing field and reduced the scale of exclusion due to unfavorable location of companies. In the competitive struggle it is no longer the location, but other factors, such as prices, customer relations or the company's image, that have started to play a decisive role. This has brought a number of benefits to customers, manufacturers and economies as a whole. Creation of virtual space has become an impulse and catalyst for globalization processes. With the growing importance of virtual space, economic paradigms have also changed - another role is played by territory (traditional space), distance, infrastructure and transport suprastructure, logistics, location of retail and service outlets, as well as bank branches.

The impact of these new management conditions on the functioning of the micro, small and medium-sized enterprises (SME) sector is analyzed in this paper. Changes in the patterns of using banking services by SMEs in the conditions of progressive digitization of these services were selected as the main research problem. The authors were interested in changes in the processes of bank selection, in particular the role of branch locations, as well as changes in the ways/places of using basic banking services, such as: checking the history of operations, making transfers, opening deposits or submitting credit applications.

The aim of this publication is to present and interpret the results of many years of empirical research on the changing banking behavior of SMEs in Poland in the context of spatial exclusion or spatial 'justice'. In this article, spatial justice (or spatial equity) is understood in a traditional way as the economic and spatial accessibility of public services (including banking services) according to what can be found in the literature on the subject (see e.g. Boyne, 1991; Talen \& Anselin, 1998). It should be remembered that the commonly accepted definition of spatial justice is, however, broader: 'intentional and focused emphasis on the spatial or geographical aspects of justice and injustice' (Soya, 2009, p. 2), i.e. it also covers, for example, spatial disparities in quality of life, poverty and the functioning of labor markets. As Rauhut (2017) argues, this justice includes not only static elements (differentiation or access status), but also an element of management decisions, i.e. issues of influence and deciding on the desired state of differentiation. Despite an abundance of studies, this concept remains undefined (Quentin \& Morange, 2018), hence the common tendency to its practical operationalization within the framework of empirical research, as it has been done in this paper.

Apart from numerous publications on banking, SME sector or knowledge-based economy, due to the dynamics of economic processes, we do not hold the full knowledge (or this knowledge quickly becomes outdated) about how the mechanisms of competition transform along with development of digital economy. There are also some gaps in the knowledge about the changing market behaviors of SME in the new economic conditions. Studies on services of general economic interest conducted earlier in Poland mainly concerned the access of residents to services such as gas, water, sewage and waste disposal, electricity and transport (Świątek, Komornicki \& Siłka, 
2013), so they omitted banking and SME issues. The influence of spatial location of these services on competitive capacity of local economy during the crisis in Poland (Komornicki, Zaucha, Szejgiec \& Wiśniewski, 2015) was not examined either. Banking services were also not included in the analysis of territorial capital in Poland (Zaucha et al., 2015; Komornicki \& Ciołek, 2017).

The contribution of this publication to the science consists in showing the mechanisms of spatial behavior of SMEs in the conditions of progressive digitalization of banking services, as well as differences in the use of traditional and electronic distribution channels of banking services by representatives of various business segments. These results make it possible to relate these changes to spatial justice. The research is of an interdisciplinary nature - it covers issues related to economics, finance, management, banking, economic geography and entrepreneurship.

At the beginning, the basic categories or concepts used in this paper will be defined: traditional space, virtual space, spatial justice, fair access, socially important goods and services.

Traditional space is understood as surface of the Earth (area) where objects (in this case the company's headquarters and a bank branch) are located at a certain distance (in this research measured in kilometers). If a company uses banking services in traditional banking branches, each time the owner or employee covers a certain distance, it generates costs. They may be related to expenditure on different modes of transport, but their time dimension is even more important. If an employee arranges banking business, the cost will be the hourly wage rate multiplied by the time spent on banking business. We deal with a much higher cost when banking matters are handled by the owner of the enterprise (which happens very often in micro companies - employing up to 9 employees). In the traditional space, there may therefore be a large variation in the costs of using banking services.

Virtual space is understood as an artificial, digital reality created by man using computers, servers, routers, software, telecommunication devices, in which users interact in various ways and in which different types of services are exchanged. Access to this space requires specific devices and a subscription fee for using Internet services, but if the condition of access to the Web is already met, then the differences in costs of using, e.g. Internet banking or mobile banking by enterprises are small. From a physical point of view, each entrepreneur is separated from their bank by the distance they have to an Internet-connected device, e.g. a computer or smartphone.

Related or even synonymous terms 'spatial justice' and 'fair access' mean a situation where the location of the company does not significantly differentiate the costs (expressed directly in money or indirectly in units of time) and does not limit (or even prevent) the use of the services in question (in this case banking services). The research results quoted later in the article show that in the economic reality we often face spatial injustice, unequal access, spatial division or even spatial discrimination in the case of companies located in peripheral areas.

Banking services belong to the group of key services supporting the functioning of the economy and are included in the group of socially important services. The European Commission (2013, p. 21) defines the term as follows:

services of general economic interest are an economic activity sector that offers services of general public interest that would not be provided on the market (or would be provided under different conditions in terms of quality, safety, affordability, equal treatment or universal access) without public intervention. 


\section{Literature review}

Scientific literature ${ }^{1}$ considers the location of bank branches as well as the role of virtual space from the point of view of various stakeholders (see Fig. 1).

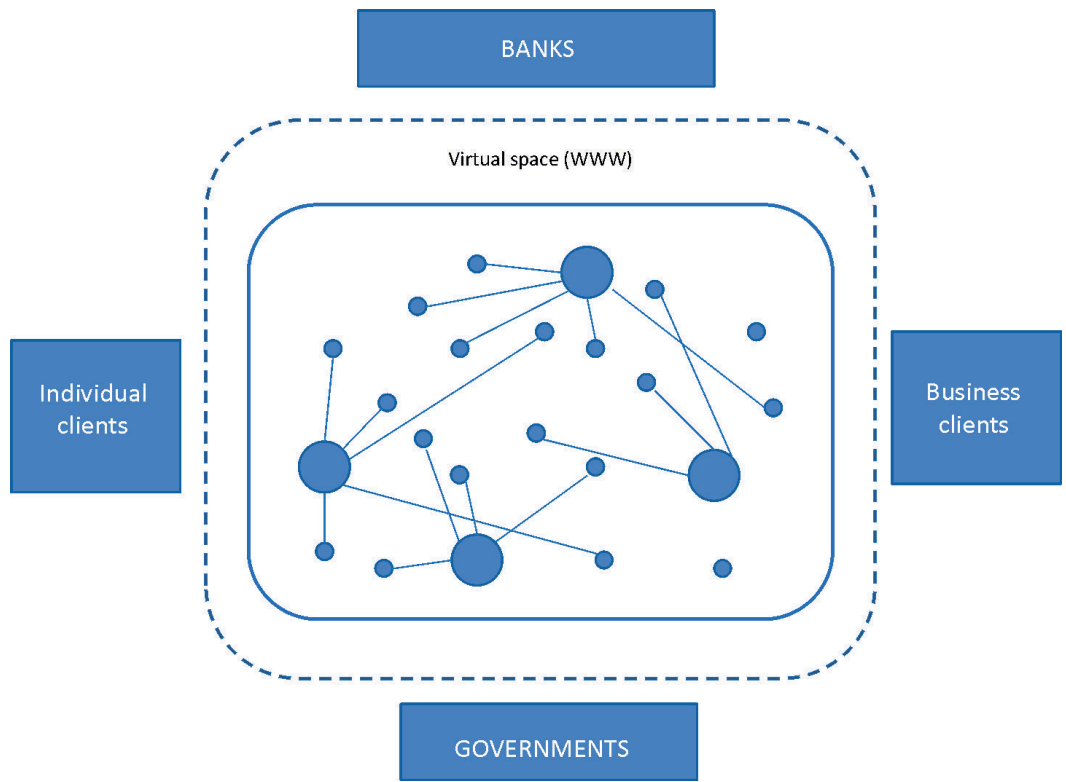

Figure 1. Key stakeholders in banking operations in traditional and virtual space Source: authors' own study.

In banking, special attention has been paid to optimizing the location of branches for plenty of years. The idea was to use the available geographically presented information (GIS) to select the regions with the highest potential for deposit raising, lending and basic transactional operations (see e.g. Felici \& Pagnini, 2008).

In the 1990s, with the technological revolution and the introduction of electronic financial services, banks began to rationalize their distribution networks by reducing the number of traditional branches. This triggered protests from customers who were accustomed to service in stationary branches.

The concept of spatial exclusion has emerged in the scientific literature, related to customers living or operating in peripheral areas, far from large urban agglomerations or in poorer neighborhoods (Leyshon \& Thrift, 1996; Brevoort \& Hannan, 2006; Leyshon, French \& Signoretta, 2008; Hegerty, 2016).

Governments and regulators started to examine the situation of different customer groups and analyze whether competition mechanisms were distorted, in particular whether banks restrict customer access to key services by mergers and acquisitions and subsequent closures (see e.g. the UK Competition Commission report - CC, 2002).

\footnotetext{
${ }^{1}$ Within the framework of literature studies, the following databases of magazines, articles and quotations were used: Web of Science, EBSCOhost, Science Direct, JSTOR, Emerald and SpringerLink. Keywords and phrases were entered in the search engines, including: spatial justice, spatial exclusion, fair access, distance, location, bank branch and entrepreneur, business, SME, as well as bank selection criteria, virtual space. This is how over 100 articles have been collected and critically analyzed, especially from the point of view of their usefulness.
} 
Many studies concerned bank selection criteria, including the role of location, but so far most projects have focused on individual customers (see e.g. Sinkula \& Lawtor, 1988; Denton \& Chan, 1991; Kaynak, Kucukemiroglu \& Odabasi, 1991; Ta \& Har, 2000); Devlin, 2002; Devlin \& Gerrard, 2005; Katitcioglu, Tumer \& Kilinc, 2011; Hinson, Osarenkhoe \& Okoe, 2013; Saleh, Rosman \& Nani, 2013). These studies highlighted the possibility of excluding a certain group of customers from banking services, the increasing cost of travel to branches and the lack of access to financial advice due to their location in peripheral areas. Much less research was devoted to the criteria for selecting a bank among business clients (see Tumbull \& Gibbs, 1989; Zineldin, 1995, 1996).

In the scientific literature on entrepreneurship, spatial themes focused on issues of credit availability and credit costs (Krishnamurthy, 2015). US research has shown that with the growing spatial distance between a bank and a company, the likelihood of a loan being denied increases and the credit conditions themselves become worse (Degryse \& Ongena, 2002). This was explained by the asymmetry of information, referring to the key publications of economic literature in this area (Dell'Ariccia, 2001). It was assumed that the creditworthiness assessment process also takes into account so-called soft information, which is much easier to obtain for companies located in the immediate vicinity (see e.g. Berger \& Udell, 2002; Peterson \& Rajan, 2002; Agarwal \& Hauswald, 2010).

Over the last decade, many studies have focused on modern distribution channels for banking services and changing customer behavior patterns (e.g. Berger \& DeYoung, 2006; Xue, Lorin \& Pei$\mathrm{yu}, 2011)$. There was a rapid increase in the popularity of online and afterwards mobile banking (using smartphones). Research has shown that distribution models gradually evolved from single-channel to multichannel banking and eventually into omnichannel banking (i.e. all possible distribution channels available to customer).

As far as virtual space is concerned, we also deal with the phenomena of exclusion (digital exclusion) and division (digital divide). These relate to lack of network access, lack of broadband services or lack of competence in the use of WWW resources and communication skills in virtual space (among others Forman, 2005; Arbore \& Ordanini, 2006; Labrianidis \& Kalogeressis, 2006; Galliano \& Roux, 2008; Batorski, 2009; Grimes, Ren \& Stevens, 2012; Bach, Zoroja \& Vukšić, 2013).

\section{Methodology of empirical research}

The authors of this paper were conducting cyclical (once a year) surveys of financial behavior of SMEs in Poland for 9 years (2007-2015). The sizes of the survey samples are presented in Table 1.

Table 1. Characteristics of the survey samples

\begin{tabular}{|c|c|c|c|c|}
\hline Year & $\begin{array}{c}\text { Micro enterprises } \\
(\mathbf{0 - 9 )}\end{array}$ & $\begin{array}{c}\text { Small enterprises } \\
\mathbf{( 1 0 - 4 9 )}\end{array}$ & $\begin{array}{c}\text { Medium-sized enterprises } \\
\mathbf{( 5 0 - 2 4 9 )}\end{array}$ & $\begin{array}{c}\text { Total SME } \\
\text { (0-249) }\end{array}$ \\
\hline 2007 & 572 & 472 & 264 & 1308 \\
\hline 2008 & 603 & 484 & 239 & 1326 \\
\hline 2009 & 607 & 486 & 253 & 1346 \\
\hline 2010 & 1018 & 505 & 289 & 1812 \\
\hline 2011 & 709 & 503 & 257 & 1469 \\
\hline 2012 & 612 & 318 & 164 & 1094 \\
\hline 2013 & 603 & 300 & 200 & 1103 \\
\hline 2014 & 600 & 300 & 200 & 1100 \\
\hline 2015 & 600 & 300 & 200 & 1100 \\
\hline
\end{tabular}


Each year, the samples were drawn using the stratified sampling technique. The drawing was operated by the REGON database (Polish official business register held by Polish Statistics), containing data on 4 million business entities. Companies in 3 size segments were drawn separately, controlling the types of activity and the voivodeship in which the company was located. The REGON database was used to determine the amounts.

Disproportionate samples were used in the research in order to obtain a broader knowledge not only about micro, but also about small and medium-sized enterprises. If proportional samples were used, more than $95 \%$ of interviews would be conducted in micro enterprises. A weighting system was used to obtain data for the whole SME sector.

The scope of research on traditional and virtual space covered mainly: the criteria for selecting a bank for current service and the use of various banking services in particular distribution channels (including branches and electronic channels).

The following hypotheses were put forward when starting the research:

H1: Significance of location as a factor for selecting a bank keeping a company's transactional account will decrease over time due to development of electronic services.

$\mathrm{H} 2$ : Virtual space will change the competition mechanisms in banking - in conditions of better access to information, the significance of fees and commissions when selecting a bank will be higher. H3: Location of a branch as a bank selection criterion will be most important in the sector of micro enterprises.

H4: Virtual space will be used first of all to distribute less complex banking services.

$\mathrm{H} 5$ : As the distance between a company and a bank branch locations increases, the percentage of companies taking advantage of loans decreases.

H6: As the distance between a company and a bank branch locations increases, the percentage of companies that are denied credit increases.

The first hypothesis $(\mathrm{H} 1)$ is related to behavioral patterns of economic operators. More and more SMEs use the Internet, performing more and more operations in the network. Internet banking has already lost its status as a new, insecure service. It is widely used, year by year the trust in this type of service is growing and the use of Internet services is increasing at the expense of traditional services. This should be reflected in a decrease in the importance of the location in the process of selecting a bank by SMEs.

The second hypothesis $(\mathrm{H} 2)$ is related to the first one; if the role of branch location is decreasing, then other factors must replace it in the process of bank selection. Given the increasing access to information and the possibility to use price comparison engines, it was considered that prices would play an increasingly important role in the bank selection process.

The third hypothesis $(\mathrm{H} 3)$ is related to the question of time and money. In micro companies, where the owner personally handles many financial and banking matters, every hour spent on e.g. commuting to the bank or standing in line at a branch office, is reflected in real financial losses of the company. In larger companies, more cases are delegated to employees. These are the financial and accounting officers who make transfers and contact the bank in current affairs.

The fourth hypothesis $(\mathrm{H} 4)$ is based on global research findings. This research shows that bank customers most often review the history of operations and make transfers within the framework of online banking. In the case of more complex services, such as loans, customers still prefer to use traditional outlets where they can discuss and explain everything with a bank employee.

The fifth ( $\mathrm{H} 5)$ and sixth (H6) hypotheses are related to the results of US research (Degryse \& Ongena, 2002). It was assumed that in the case of limited access to so-called private (informal) information for companies located at a greater distance, banks would try to reduce risk and lend less to such entities. 


\section{Research results}

\section{Economic background}

Before presenting detailed research results, the economic background of the analysed events in Poland should be presented - changes in the banking system and the role of the SMEs sector.

As part of the political transformation (1988-1992), a completely new banking system was created in Poland, adapted to the needs of the market economy. In the period covered by the analyses (2007-2015), significant structural and technological changes took place in the Polish banking system. The banking sector's assets increased from PLN 797 billion to PLN 1,595 billion (NBP, 2017). At the beginning of the study (2007), 61 commercial banks were operating in Poland (including 40 with a predominance of foreign capital) and 581 cooperative banks (NBP, 2008). At the end of the study (2015), 63 commercial banks were operating in Poland (including 26 with a predominance of foreign capital, mainly from Italy, Germany, Spain, France, the Netherlands and the USA) and 560 cooperative banks (NBP, 2016).

Initially the number of branches increased from 5,595 in 2007 to 7,530 in 2012, to decrease to 7,214 during subsequent years (in 2015) (KNF, 2019). The situation was similar for sub-branches, agencies, representative offices and other units. Their number increased from 7,242 in 2007 to 7,934 in 2013, and in subsequent years it dropped to 7,218 (2015) (KNF, 2019). The decrease in the number of branches and bank offices was associated with technological changes and the rapidly growing popularity of online banking. Due to extensive investments in new technologies and product innovations, banks operating in Poland regarded as European leaders in the field of digital banking (Deloitte, 2018).

The SMEs sector plays a key role in the Polish economy. In 2015, the number of active micro-sized enterprises conducting non-financial activities was 1,838.4 thousand, small-sized enterprises - 56.7 thousand, medium-sized enterprises - 15.6 thousand, and large companies 3.4 thousand (PARP, 2018). In 2015, the share of gross added value generated by the SMEs sector in GDP amounted to $49.9 \%$ (including $30.5 \%$ in micro-sized enterprises, $8.1 \%$ in small-sized enterprises, $11.3 \%$ in medium-sized enterprises), and $24.1 \%$ in large companies (the remaining $26.0 \%-$ the government sector; PARP, 2018). The SMEs sector employed 6.7 million people, i.e. $69.1 \%$ of all persons employed in the enterprise sector (including micro-sized enterprises $-39.0 \%$, small-sized enterprises $-12.7 \%$ and medium-sized enterprises $-17.4 \%)$, while the share of large companies was only $30.9 \%$ (PARP, 2018).

Categories such as market and competition occupy a central place in economic research. Much space is devoted to market failures and distortions of competition mechanisms. In Poland, despite the aforementioned key importance of the SMEs sector in the economy, the smallest business entities (micro-sized enterprises) have to deal with worse conditions of cooperation with banks and are more often faced with denial of credit than in the case of medium-sized enterprises. Although these phenomena (e.g. higher interest rates on loans) have their justification in the form of information asymmetry, higher risk, lower creditworthiness of small entities or a price differentiation policy depending on the scale of operations, it is difficult to define the conditions of the market game as 'fair competition'. We can see a kind of market injustice, unequal access to services or even discrimination against the smallest and economically weakest entities that get the financial products and services at less favourable price conditions. The authors are aware that 'fairness' is a value-laden term. Therefore in this paper fairness is narrowly interpreted as an equal access to the banking system for all types of enterprises. 
The worse treatment of the smallest business entities by banks was observed by the authors of the presented research. In 2015, in the group of micro-sized enterprises the percentage of enterprises taking up loans amounted to $15.0 \%$, in the group of small-sized enterprises $-26.7 \%$, and in the group of medium-sized enterprises $-33.0 \% .5 .7 \%$ of the surveyed micro-sized enterprises faced difficulties in accessing loans, while in the group of small-sized enterprises this indicator was $3.7 \%$, and in the group of medium-sized enterprises only $0.5 \%$. Among the difficulties in accessing loans, the most frequent were: refusal to grant a loan / extension of the credit line, smaller amount of the loan than the one requested, refusal to extend the credit line and the requirement for additional credit insurance or additional collateral. This affected the ability to make investments. In the group of micro-sized enterprises the percentage of investing companies was only $31.2 \%$, in the group of small-sized enterprises $50.7 \%$, and in the group of medium-sized enterprises $70.0 \%$. The micro-sized enterprises also less frequently used the financial consulting services (11.7\%); with ratios of $19.0 \%$ in small-sized enterprises and $24.0 \%$ in medium-sized enterprises; bank guarantees (1.0\%); while $3.0 \%$ in small-sized enterprises and $10.0 \%$ medium-sized enterprises or factoring (1.2\%); $2.7 \%$ in small-sized enterprises and $5.5 \%$ in medium-sized enterprises.

The indicators of satisfaction with cooperation with the bank and the propensity to recommend the bank to other companies were also assessed as part of the research. The lowest satisfaction rates were recorded in the micro-sized companies segment. A 5-point scale was used for comparative analyses, on which 1 point meant very low, and 5 points - very high level of satisfaction. Micro-sized enterprises clearly rated lower: deposit conditions: 3.57 points (with 3.85 points in small-sized enterprises and 3.87 points in medium-sized enterprises) and loan terms: 3.65 points (with 3.78 points in small-sized enterprises and 3.86 points in medium-sized enterprises. Electronic banking was the only element rated at a similar level -4.51 points in micro-sized companies, 4.48 points in small-sized enterprises and 4.50 points in medium-sized companies. The lowest propensity to recommend a bank (Net Promoter Score) was recorded in micro-sized enterprises at $24.0 \%$, while in small-sized enterprises $37.3 \%$, and in medium-sized enterprises $35.5 \%$.

The market failures mentioned above force the government to intervene in the form of, for example, lower taxation, grants and subsidies, guarantees and special credit lines for the SMEs sector, which is to equalize the conditions of the market game.

\section{Bank selection criteria}

The hierarchical scale was used to study the criteria for selection of a bank by entrepreneurs. Respondents marked only three most important factors of bank selection for current service (taken into account at the moment of opening an account) by typing: 1 - for the most important factor, 2 - for the second factor, and 3 - for the third factor in terms of importance.

A linear trend model was used to assess and describe the trends of changes for all analyzed indicators. This choice was dictated by too few observations over time to fit more complex models and the desire to maintain comparability of results. Due to the adopted model, it is obviously not possible and appropriate to extrapolate the values of indicators for subsequent years, but the main objective was to describe the existing trends. For the estimated models, the tables present the regression coefficient (the slope), coefficient of determination and the assessment of the significance of the slope.

According to the first hypothesis ( $\mathrm{H} 1$ ) significance of location as a factor for selecting a bank keeping a company's transactional account will decrease over time due to development of electronic services. In the first year of the survey (2007), convenient locations were ranked first among the 3 key 
selection factors most frequently (29\%). However, in the following years, the percentage of entrepreneurs declaring that a convenient location is the most important for them when choosing a bank was gradually decreasing, reaching its lowest value in 2012 (14\%) and 2015 (16\%), which confirms the first research hypothesis (Table 2). The location of the bank's branch lost its importance as the main factor taken into account; on average, year by year, the percentage indicating this criterion decreased by $1.4 \mathrm{pp}$ (65\% of the variability of the ratio explained by the statistically significant model).

It is also worth noting that in 2010 the vast majority (67.4\%) of the surveyed enterprises chose a bank to provide day-to-day services that was located at a distance of not more than $3 \mathrm{~km}$ (Table 3). This meant that at that time, in order to secure a significant market share and further expansion, banks had to build a very wide distribution network based on traditional branches (at peak times there were over 14,000 branches). With the development of virtual space in 2010 2015, the number of traditional bank branches in Poland decreased from 14,179 at the end of 2010 to 11,890 in 2015 and 9,600 in July 2019 (KNF, 2019).

Table 2. Bank selection criteria in the SME sector - the first place indications (in \%)

\begin{tabular}{|c|c|c|c|c|c|c|c|c|c|c|c|c|}
\hline Bank selection criteria & 2007 & 2008 & 2009 & 2010 & 2011 & 2012 & 2013 & 2014 & 2015 & b & $\mathbf{R}^{2}$ & c.l. \\
\hline Convenient location & 29 & 23 & 22 & 16 & 20 & 14 & 16 & 17 & 16 & -0.0140 & $64.8 \%$ & $* * *$ \\
\hline $\begin{array}{l}\text { Low account fees / low } \\
\text { service fees }\end{array}$ & 28 & 31 & 34 & 38 & 31 & 33 & 32 & 36 & 36 & 0.0063 & $31.0 \%$ & \\
\hline $\begin{array}{l}\text { An owner having a } \\
\text { personal account in this } \\
\text { bank }\end{array}$ & 13 & 12 & 12 & 11 & 14 & 13 & 8 & 9 & 9 & -0.0052 & $45.0 \%$ & $* *$ \\
\hline $\begin{array}{l}\text { Advancement of service } \\
\text { (electronization) / } \\
\text { Internet }\end{array}$ & 10 & 11 & 11 & 9 & 11 & 11 & 11 & 9 & 10 & -0.0007 & $4.4 \%$ & \\
\hline $\begin{array}{l}\text { Security of the funds } \\
\text { entrusted / trust in the } \\
\text { bank }\end{array}$ & 8 & 10 & 10 & 11 & 8 & 13 & 12 & 8 & 8 & 0.0000 & $0.0 \%$ & \\
\hline $\begin{array}{l}\text { Reputation of the bank } \\
\text { / favorable image }\end{array}$ & 5 & 4 & 3 & 5 & 5 & 5 & 7 & 6 & 6 & 0.0030 & $49.6 \%$ & $* *$ \\
\hline $\begin{array}{l}\text { Comprehensiveness of } \\
\text { service / offer range }\end{array}$ & 2 & 3 & 3 & 4 & 3 & 3 & 5 & 6 & 6 & 0.0047 & $77.4 \%$ & $* * *$ \\
\hline Interesting credit offer & 1 & 1 & 1 & 1 & 2 & 2 & 3 & 2 & 2 & 0.0020 & $60.0 \%$ & $* *$ \\
\hline $\begin{array}{l}\text { The bank was } \\
\text { recommended by } \\
\text { friends }\end{array}$ & 1 & 1 & 2 & 2 & 3 & 2 & 1 & 3 & 3 & 0.0020 & $40.0 \%$ & $*$ \\
\hline $\begin{array}{l}\text { Speed of service / no } \\
\text { queues }\end{array}$ & 1 & 1 & 1 & 1 & 2 & 1 & 1 & 2 & 2 & 0.0012 & $40.8 \%$ & $*$ \\
\hline $\begin{array}{l}\text { Staff competence / } \\
\text { courtesy }\end{array}$ & 0 & 1 & 1 & 1 & 0 & 1 & 1 & 2 & 2 & 0.0018 & $50.4 \%$ & $* *$ \\
\hline $\begin{array}{l}\text { Advertisement / } \\
\text { promotion of the } \\
\text { account }\end{array}$ & 0 & 0 & 0 & 0 & 1 & 0 & 0 & 0 & 0 & 0.0000 & $0.0 \%$ & \\
\hline Other & 1 & 1 & 1 & 3 & 0 & 0 & 2 & 2 & 1 & 0.0003 & $0.9 \%$ & \\
\hline
\end{tabular}

$\mathrm{b}$ - the slope of linear trend function (average year-by-year increase/decrease);

$\mathrm{R}^{2}$ - coefficient of determination of the trend model;

c.l. - critical level of the test for significance of the slope: *** - significant at 0.01 significance level, ** - significant at 0.05 significance level, ${ }^{*}$ - significant at 0.10 significance level. 
Table 3. Distance of company seat from bank branch (distribution of responses) in 2010

\begin{tabular}{|l|c|c|}
\hline \multicolumn{1}{|c|}{ Distance } & Number of responses & Percentage of responses \\
\hline Up to $1 \mathrm{~km}$ & 527 & 32.0 \\
\hline $2-3 \mathrm{~km}$ & 584 & 35.4 \\
\hline $4-5 \mathrm{~km}$ & 248 & 15.0 \\
\hline $6-10 \mathrm{~km}$ & 210 & 12.9 \\
\hline More than $10 \mathrm{~km}$ & 80 & 5.0 \\
\hline Total & 1649 & 100.0 \\
\hline
\end{tabular}

Between 2007 and 2015, the role of low fees and commissions increased from 28\% in 2007 to $36 \%$ in 2015. (see Table 2), which is in line with the second research hypothesis (H2) stating that in conditions of better access to information, the significance of fees and commissions when selecting a bank will be higher. However, the linear trend model was statistically insignificant and had a relatively low fit, which was mainly due to the results of the 2010 survey ( $38 \%$ of indications, the highest indicator in the period under review). 2010 was the year of the culmination of crisis phenomena in the world. Poland experienced a slowdown in the economic situation and an increase in unemployment. In these unfavorable conditions, companies tried to limit their expenses, which is why the amount of bank fees and commissions was so important at the time.

In the analyzed period, in selecting a bank, the importance of comprehensive service / width of the offer increased (from $2 \%$ to $6 \%$ ). The comprehensiveness of service was gaining in importance as a criterion by less than half a percentage point annually (high fit, statistically significant model), but it is still a factor pointed out in the first place by a relatively small number of entrepreneurs.

Apart from indicating the most important factors of bank selection, the total percentage of respondents' indications on one of the first three places in the hierarchy of bank selection criteria was also analyzed (Table 4). It also turned out here that the role of location is gradually decreasing (a decrease from 55\% in 2007 to 36\% in 2015), and the importance of banking services prices is growing (an increase from $52 \%$ in 2007 to $62 \%$ in 2015). Considering the three most important factors taken into account when selecting a bank, the location of the bank's branch lost its importance to a very large extent, and on average, year by year, the percentage indicating this criterion decreased by $2.25 \mathrm{pp}$ ( $86 \%$ of the variability of the ratio explained by the statistically significant model). On the other hand, the importance of low fees (average increase by over 1.1 pp year-onyear) and comprehensive service (average increase by over $0.8 \mathrm{pp}$ year-on-year) increased among the respondents. In the first case, the model was statistically significant at $10 \%$ significance level and was characterized by a rather low fit (here, too, the results of the 2010 survey were a certain anomaly). The model for the complexity of service as one of the three main criteria was characterized by a slightly higher fit, it was also statistically significant at a smaller significance level $(5 \%)$. The presented results confirm the $\mathrm{H} 1$ hypothesis in full and $\mathrm{H} 2$ hypothesis in part.

Previous research conducted by the authors suggested that the smallest economic entities (micro enterprises), a definite majority of issues related to bank services are dealt with personally by the owner. This means that a waste of time on banking activities will result in a limitation of the possibility to perform tasks generating income. Therefore, the third hypothesis ( $\mathrm{H} 3$ ) assumed that location of a branch as a bank selection criterion will be most important in the sector of micro enterprises. In each of the 9 years of the survey it was the respondents from micro companies who most often marked a convenient location as the most important factor in choosing a bank in the first place (Table 5). As far as small and medium companies are concerned, in 6 years a higher indicator was obtained in small companies, in 2 years in medium companies, and once the indicators were identical. 
Table 4. Criteria for bank selection in the SME sector - indications on one of the first three places in the selection hierarchy (in \%)

\begin{tabular}{|c|c|c|c|c|c|c|c|c|c|c|c|c|}
\hline Bank selection criteria & 2007 & 2008 & 2009 & 2010 & 2011 & 2012 & 2013 & 2014 & 2015 & b & $\mathbf{R}^{2}$ & c.l. \\
\hline Convenient location & 55 & 48 & 49 & 43 & 43 & 36 & 38 & 38 & 36 & -0.0225 & $86.1 \%$ & $* * *$ \\
\hline $\begin{array}{l}\text { Low account fees / low } \\
\text { service fees }\end{array}$ & 52 & 51 & 54 & 64 & 54 & 54 & 57 & 61 & 62 & 0.0110 & $41.2 \%$ & $*$ \\
\hline $\begin{array}{l}\text { Security of the funds } \\
\text { entrusted / trust in the } \\
\text { bank }\end{array}$ & 40 & 42 & 44 & 42 & 37 & 45 & 39 & 34 & 34 & -0.0092 & $38.8 \%$ & $*$ \\
\hline $\begin{array}{l}\text { An owner having a } \\
\text { personal account in this } \\
\text { bank }\end{array}$ & 37 & 37 & 36 & 32 & 34 & 38 & 24 & 33 & 31 & -0.0090 & $32.4 \%$ & \\
\hline $\begin{array}{l}\text { Reputation of the bank } \\
\text { / favorable image }\end{array}$ & 34 & 30 & 29 & 28 & 33 & 26 & 31 & 27 & 27 & -0.0058 & $32.8 \%$ & \\
\hline $\begin{array}{l}\text { Advancement of service } \\
\text { (electronization) / } \\
\text { Internet }\end{array}$ & 27 & 32 & 34 & 36 & 33 & 35 & 33 & 31 & 32 & 0.0023 & $6.0 \%$ & \\
\hline $\begin{array}{l}\text { Comprehensiveness of } \\
\text { service / offer range }\end{array}$ & 18 & 24 & 25 & 19 & 22 & 25 & 28 & 26 & 26 & 0.0083 & $46.3 \%$ & $* *$ \\
\hline $\begin{array}{l}\text { Speed of service / no } \\
\text { queues }\end{array}$ & 10 & 8 & 8 & 9 & 14 & 8 & 11 & 15 & 15 & 0.0077 & $48.4 \%$ & $* *$ \\
\hline Interesting credit offer & 8 & 6 & 6 & 7 & 6 & 9 & 12 & 10 & 10 & 0.0057 & $51.3 \%$ & $* *$ \\
\hline $\begin{array}{l}\text { Staff competence / } \\
\text { courtesy }\end{array}$ & 8 & 9 & 8 & 7 & 9 & 9 & 12 & 9 & 9 & 0.0023 & $21.9 \%$ & \\
\hline $\begin{array}{l}\text { The bank was } \\
\text { recommended by } \\
\text { friends }\end{array}$ & 7 & 7 & 7 & 8 & 12 & 8 & 9 & 13 & 13 & 0.0077 & $65.3 \%$ & $* * *$ \\
\hline $\begin{array}{l}\text { Advertisement / } \\
\text { promotion of the } \\
\text { account }\end{array}$ & 1 & 0 & 0 & 1 & 2 & 1 & 0 & 2 & 2 & 0.0017 & $27.8 \%$ & \\
\hline Other & 1 & 1 & 1 & 7 & 0 & 0 & 4 & 3 & 1 & 0.0008 & $1.0 \%$ & \\
\hline
\end{tabular}

b, $R^{2}$, c.l. - for explanation see Table 2.

Convenient location as the main criterion for selecting a bank was losing its importance on average over 1.3 pp year by year in small and micro enterprises. Slower decreases can be observed in the case of medium-sized companies, where the value of the indicator decreased on average year by year by less than $0.8 \mathrm{pp}$, while the level of this indicator for these companies was much lower than for micro or small companies. The parameters of trend models were statistically significant and the model was quite well fit except for the medium-sized enterprises, where in 2010 the indicator stood out from the levels from the other periods.

Table 5. Bank selection criteria in the SME sector - indications of a convenient location on the first place (in \%)

\begin{tabular}{|l|c|c|c|c|c|c|c|c|c|c|c|c|}
\hline Bank selection criteria & $\mathbf{2 0 0 7}$ & $\mathbf{2 0 0 8}$ & $\mathbf{2 0 0 9}$ & $\mathbf{2 0 1 0}$ & $\mathbf{2 0 1 1}$ & $\mathbf{2 0 1 2}$ & $\mathbf{2 0 1 3}$ & $\mathbf{2 0 1 4}$ & $\mathbf{2 0 1 5}$ & $\mathbf{b}$ & $\mathbf{R}^{\mathbf{2}}$ & c.l. \\
\hline Micro enterprises (0-9) & 30 & 23 & 23 & 16 & 20 & 15 & 18 & 17 & 17 & -0.0135 & $60.5 \%$ & $* *$ \\
\hline $\begin{array}{l}\text { Small enterprises } \\
\text { (10-49) }\end{array}$ & 22 & 20 & 15 & 13 & 12 & 14 & 16 & 10 & 8 & -0.0138 & $71.7 \%$ & $* * *$ \\
\hline $\begin{array}{l}\text { Medium-sized } \\
\text { enterprises (50-249) }\end{array}$ & 16 & 15 & 16 & 7 & 10 & 12 & 10 & 10 & 10 & -0.0077 & $43.2 \%$ & $*$ \\
\hline Total SME (0-249) & 29 & 23 & 22 & 16 & 20 & 14 & 16 & 17 & 16 & -0.0140 & $64.8 \%$ & $* * *$ \\
\hline
\end{tabular}

b, $R^{2}$, c.l. - for explanations see Table 2 . 
Two classic parametric tests were used to assess the significance of differences among the indicators for micro, small and medium-sized enterprises. The first test, based on Z statistics, allows the comparison of two proportions, in this case the comparison concerned micro enterprises and a combined group of small and medium sized enterprises (Table 6). The second test, the FisherSnedecor test, based on F statistics, allows the comparison of more than two proportions.

Apart from 2012, in all the analyzed years the significance of location for micro businesses was statistically significantly higher than for small and medium enterprises. In 2012, the percentage of indications in micro companies was also higher, but due to similar levels in medium and small companies the difference was statistically insignificant. In the whole period in question, on average, micro enterprises indicated location $50 \%$ more often than other companies. Test results confirm the $\mathrm{H} 3$ hypothesis.

Table 6. Tests for significance of differences for bank selection criteria in the SME sector - indications of a convenient location on the first place (in \%)

\begin{tabular}{|l|r|r|r|r|r|r|r|r|c|}
\hline \multicolumn{1}{|c|}{ Bank selection criteria } & $\mathbf{2 0 0 7}$ & $\mathbf{2 0 0 8}$ & $\mathbf{2 0 0 9}$ & $\mathbf{2 0 1 0}$ & $\mathbf{2 0 1 1}$ & $\mathbf{2 0 1 2}$ & $\mathbf{2 0 1 3}$ & $\mathbf{2 0 1 4}$ & $\mathbf{2 0 1 5}$ \\
\hline Micro enterprises (0-9) & 30 & 23 & 23 & 16 & 20 & 15 & 18 & 17 & 17 \\
\hline $\begin{array}{l}\text { Small and medium-sized enterprises } \\
\text { (10-249) }\end{array}$ & 20 & 18 & 15 & 11 & 11 & 13 & 14 & 10 & 9 \\
\hline In total SME (0-249) & 29 & 23 & 22 & 16 & 20 & 14 & 16 & 17 & 16 \\
\hline Stat. Z (micro vs. small + medium-sized) & 4.01 & 2.00 & 3.37 & 2.99 & 4.15 & 0.80 & 1.98 & 3.08 & 3.69 \\
\hline Critical level & 0.000 & 0.045 & 0.001 & 0.003 & 0.000 & 0.426 & 0.047 & 0.002 & 0.000 \\
\hline Significance of differences & $* * *$ & $* *$ & $* * *$ & $* * *$ & $* * *$ & & $* *$ & $* * *$ & $* * *$ \\
\hline Stat. F (micro vs. small vs. medium-sized) & 19.9 & 6.3 & 11.5 & 13.4 & 24.4 & 0.5 & 3.9 & 11.4 & 13.3 \\
\hline Critical level & 0.000 & 0.002 & 0.000 & 0.000 & 0.000 & 0.584 & 0.021 & 0.000 & 0.000 \\
\hline Significance of differences & $* * *$ & $* * *$ & $* * *$ & $* * *$ & $* * *$ & & $* *$ & $* * *$ & $* * *$ \\
\hline
\end{tabular}

In the micro-sized enterprises segment, the greater demand for services provided in traditional banking branches (e.g. cash deposits and withdrawals) was related to, among others, the method of payment for goods and services. According to the results of 2015 research, cash sales dominated in micro-sized enterprises (63.1\% of total sales). In small-size enterprises, cash sales accounted for $45.5 \%$, and in medium-size enterprises $33.4 \%$ of total sales.

Based on the literature studies on highly developed markets, it was assumed (within $\mathrm{H} 4$ ) that in Poland also: virtual space will be used first of all to distribute less complex banking services. Research has shown that entrepreneurs used Internet banking primarily to view transactions and balances on accounts and to make transfers (Table 7). Year by year, the popularity of opening and withdrawing Internet banking deposits also grew. The average year-by-year increase in Internet transactions was most visible in basic operations, such as viewing balances and making transfers, which grew by 4.5 pp to almost $90 \%$ in 2015 . Slower growth, on average by 2.4 pp per year, is observed in the less popular deposit transaction. The parameters of trend models are statistically significant and they reflect the course of change well.

Table 7. Internet banking operations - indications of using types of banking services (in \%)

\begin{tabular}{|l|c|c|c|c|c|c|c|c||c|c|c|}
\hline \multicolumn{1}{|c|}{ Banking operations } & $\mathbf{2 0 0 8}$ & $\mathbf{2 0 0 9}$ & $\mathbf{2 0 1 0}$ & $\mathbf{2 0 1 1}$ & $\mathbf{2 0 1 2}$ & $\mathbf{2 0 1 3}$ & $\mathbf{2 0 1 4}$ & $\mathbf{2 0 1 5}$ & $\mathbf{b}$ & $\mathbf{R}^{\mathbf{2}}$ & c.l. \\
\hline Viewing operations / balances & 54 & 68 & $\mathbf{7 2}$ & 65 & 90 & 86 & 84 & 88 & 0.0458 & $74.2 \%$ & $* * *$ \\
\hline Making transfers & 51 & 60 & 68 & 69 & 78 & 80 & 78 & 86 & 0.0452 & $91.7 \%$ & $* * *$ \\
\hline Opening / withdrawing deposits & 18 & 26 & 27 & 36 & 36 & 33 & 35 & 38 & 0.0242 & $74.6 \%$ & $* * *$ \\
\hline
\end{tabular}

b, $R^{2}$, c.l. - for explanations see Table 2 . 
According to the survey results, the role of branches in the case of simple banking operations decreased year by year (Table 8). However, where staff support or advice is required (e.g. when opening or withdrawing deposits), the organizations still played a key role. The fastest average decrease was observed in the percentage of companies that placed credit transfer orders in bank branches (average year-by-year decrease by $4.2 \mathrm{pp}$ ). Also browsing the history of the account or checking balances in the branches was becoming less and less frequent, with an average decrease of almost $4 \mathrm{pp}$ year by year. Trend models in both cases can be considered statistically significant, but are quite poorly fit to the data due to considerable fluctuations in the level of indicators. On the other hand, the decrease in the percentage of enterprises setting up deposits in branches was much slower, on average it was less than a percentage point, but the model in this case is very poorly adjusted and statistically insignificant.

Table 8. Operations in banking branches - indications of using types of banking services (in \%)

\begin{tabular}{|l|c|c|c|c|c|c|c|c|c|c|c|}
\hline \multicolumn{1}{|c|}{ Banking operations } & $\mathbf{2 0 0 8}$ & $\mathbf{2 0 0 9}$ & $\mathbf{2 0 1 0}$ & $\mathbf{2 0 1 1}$ & $\mathbf{2 0 1 2}$ & $\mathbf{2 0 1 3}$ & $\mathbf{2 0 1 4}$ & $\mathbf{2 0 1 5}$ & $\mathbf{b}$ & $\mathbf{R}^{\mathbf{2}}$ & c.I. \\
\hline Viewing operations / balances & 53 & 47 & 31 & 52 & 35 & 19 & 25 & 29 & -0.0394 & $56.7 \%$ & $* *$ \\
\hline Making transfers & 74 & 72 & 46 & 30 & 55 & 33 & 43 & 46 & -0.0423 & $40.4 \%$ & $*$ \\
\hline Opening / withdrawing deposits & 53 & 54 & 50 & 53 & 58 & 41 & 47 & 51 & -0.0085 & $16.4 \%$ & \\
\hline
\end{tabular}

b, $R^{2}$, c.l. - for explanations see Table 2 .

In the last year of the research (2015), entrepreneurs were also asked about submitting credit applications through various distribution channels. It turned out that entrepreneurs prefer to apply for loans in traditional banking branches (Table 9).

Table 9. Operations in various distribution channels (percentage of enterprises) in 2015

\begin{tabular}{|l|c|c|c|}
\hline \multicolumn{1}{|c|}{ Banking operations } & Branch & Internet banking & Mobile banking \\
\hline Viewing operations / balances & 45.7 & 86.3 & 11.1 \\
\hline Making transfers & 28.6 & 87.5 & 4.1 \\
\hline Opening / withdrawing deposits & 50.5 & 38.2 & 0.3 \\
\hline Credits & 69.3 & 40.7 & 0.8 \\
\hline
\end{tabular}

In 2011-2015, entrepreneurs were asked which channel they consider to be the most important (basic) one for the distribution of banking products (Table 10). The surveyed companies most often pointed to Internet banking as the basic channel for using banking products, and the role of virtual services was growing year by year. In the case of the micro enterprises group, we can observe an increase in the importance of Internet banking as the primary channel, the percentage of indications grew on average by almost $3 \mathrm{pp}$. The trend model was characterized by a high fit, and it is statistically significant at a significance level of 0.05 . For small and medium-sized enterprises, the increases were much lower, as the models were statistically insignificant and very poorly matched due to a small number of observations over time.

Table 10. Internet banking treated as the basic channel of using banking services (percentage of indications)

\begin{tabular}{|l|r|r|r|r|r|r|r|r|}
\hline \multicolumn{1}{|c|}{ Group of enterprises } & $\mathbf{2 0 1 1}$ & $\mathbf{2 0 1 2}$ & $\mathbf{2 0 1 3}$ & $\mathbf{2 0 1 4}$ & $\mathbf{2 0 1 5}$ & b & $\mathbf{R}^{\mathbf{2}}$ & c.l. \\
\hline Micro enterprises (0-9) & 53.3 & 60.5 & 62.4 & 61.8 & 67.2 & 0.0291 & $84.2 \%$ & $* *$ \\
\hline Small enterprises (10-49) & 64.2 & 66.4 & 76.7 & 61.7 & 68.7 & 0.0043 & $1.4 \%$ & \\
\hline Medium-sized enterprises (50-249) & 63.8 & 70.7 & 74.5 & 66.0 & 70.5 & 0.0087 & $10.6 \%$ & \\
\hline Total SME (0-249) & 54.0 & 60.8 & 63.2 & 61.9 & 67.3 & 0.0277 & $82.1 \%$ & $* *$ \\
\hline
\end{tabular}

b, $R^{2}$, c.l. - for explanations see Table 2 . 
Banking branches were indicated in the following years by fewer and fewer respondents as the most important channel for the use of banking services (Table 11). According to the results for the Internet as the basic channel in the case of branches as the main source of banking services, the model is statistically significant only for the micro enterprises, with the significance level of 0.10 , and it is characterized with a good fit. According to the model, we observe a decrease in the percentage of indications by $2.4 \mathrm{pp}$ from year to year on average. In the case of small and medium-sized enterprises, changes are slower and the models are mismatched and statistically insignificant.

Table 11. Bank branches treated as the basic channel of using banking services (percentage of indications)

\begin{tabular}{|l|c|c|c|c|c|c|r|c|}
\hline \multicolumn{1}{|c|}{ Group of enterprises } & $\mathbf{2 0 1 1}$ & $\mathbf{2 0 1 2}$ & $\mathbf{2 0 1 3}$ & $\mathbf{2 0 1 4}$ & $\mathbf{2 0 1 5}$ & $\mathbf{b}$ & $\mathbf{R}^{\mathbf{2}}$ & c.I. \\
\hline Micro enterprises (0-9) & 41.0 & 34.2 & 30.7 & 33.5 & $\mathbf{2 9 . 5}$ & -0.0237 & $70.0 \%$ & $*$ \\
\hline Small enterprises (10-49) & 33.0 & 30.8 & 20.3 & 33.3 & 28.0 & -0.0075 & $4.9 \%$ & \\
\hline Medium-sized enterprises (50-249) & 31.5 & 26.2 & 21.5 & 29.0 & 26.0 & -0.0082 & $12.0 \%$ & \\
\hline Total SME (0-249) & 40.5 & 34.0 & 30.0 & 33.5 & 29.4 & -0.0227 & $65.8 \%$ & $*$ \\
\hline
\end{tabular}

b, $R^{2}$, c.l. - for explanations see Table 2 .

The research also verified whether there is a phenomenon of spatial discrimination of SMEs in Poland, where the asymmetry of information is much bigger than in the case of large corporations, but no interdependencies were observed as to the distance between the company's seat and the bank branch, and the indicator of using credits or rejections to award a credit (see Tables 12 and 13). This may be due to the way in which creditworthiness is assessed and the use of different sources of information. In Poland, large banks have centralized credit procedures. Credit applications are most often submitted to analysts working at the head office and not at a local branch. The assessments use hard data and scoring systems, rather than soft information from various informal sources.

Based on the ANOVA test one can argue that there are statistically significant differences between the physical distance of the company's office from the bank branch for companies which use and those which do not use loans from the bank. Companies not taking any loans are on average $3.7 \mathrm{~km}$ away from the bank's branch, whereas companies using the loans are one kilometer more away. However, this relation is very weak (Eta coefficient is only 0.08 ) and the significance of the result is mainly determined by a large sample size of more than 1500 companies. Based on the independence test $\chi^{2}$ for contingency table, the statistically significant stochastic relationship between the use of loans and the distance from a bank facility was confirmed. The relationship is very weak (V-Kramer coefficient of 0.12) and completely non-linear; enterprises located at a largest and medium distance from the bank facility use the loans more often than those located closest to the banks. The $\mathrm{H} 5$ hypothesis has not been confirmed - in the SME sector in Poland the distance does not affect the probability of using loans.

Table 12. Use of loans (in \%) and the distance of the company's office from the bank branch

\begin{tabular}{|l|c|c|c|c|c|}
\hline Use of loans & $\begin{array}{c}\text { Up to } 1 \mathbf{~ k m} \\
(\mathbf{n}=\mathbf{5 2 7})\end{array}$ & $\begin{array}{c}\mathbf{2 - 3} \mathbf{~ k m} \\
(\mathbf{n}=\mathbf{5 8 4})\end{array}$ & $\begin{array}{c}\mathbf{4}-6 \mathbf{~ k m} \\
(\mathbf{n}=\mathbf{3 0 2})\end{array}$ & $\begin{array}{c}\mathbf{7 - 1 0} \mathbf{~ k m} \\
(\mathbf{n}=\mathbf{1 5 6})\end{array}$ & $\begin{array}{c}\text { More than } 10 \mathbf{~ k m} \\
(\mathbf{n}=\mathbf{8 0})\end{array}$ \\
\hline No & 81.4 & 76.4 & 67.2 & 78.8 & 70.0 \\
\hline Yes & 18.6 & 23.6 & 32.8 & 21.2 & 30.0 \\
\hline
\end{tabular}


The ANOVA test for the differences between mean values indicates that there are no statistically significant differences in the distance when it comes to enterprises that were granted and denied a loan. Similar result was obtained using the $\chi^{2}$ independence test. The relationship is very weak (V-Kramer coefficient equals 0.04) and statistically insignificant. The H6 hypothesis has not been confirmed - the distance has no influence on the decision to refuse the loan.

Table 13. Refusal of a loan (in \%) and a distance of the company's office to the bank branch

\begin{tabular}{|l|c|c|c|c|c|}
\hline Refusal of a loan & $\begin{array}{c}\text { Up to } \mathbf{1 ~} \mathbf{~ k m} \\
(\mathbf{n = 5 1 4 )}\end{array}$ & $\begin{array}{c}\mathbf{2 - 3} \mathbf{~ k m} \\
(\mathbf{n = 5 5 8})\end{array}$ & $\begin{array}{c}\mathbf{4 - 6} \mathbf{~ k m} \\
(\mathbf{n}=\mathbf{2 9 9})\end{array}$ & $\begin{array}{c}\mathbf{7 - 1 0} \mathbf{~ k m} \\
(\mathbf{n = 1 5 6})\end{array}$ & $\begin{array}{c}\text { More than } \mathbf{1 0} \mathbf{~ k m} \\
(\mathbf{n = 7 9 )}\end{array}$ \\
\hline No & 96.3 & 96.6 & 94.6 & 97.4 & 94.9 \\
\hline Yes & 3.7 & 3.4 & 5.4 & 2.6 & 5.1 \\
\hline
\end{tabular}

\section{Conclusions}

The emergence of virtual space has changed the functioning of the banking services market in Poland. Access to services has become easy and inexpensive. The phenomenon of spatial discrimination of economic entities located in peripheral areas has decreased.

The first hypothesis ( $\mathrm{H} 1)$ has been confirmed in empirical studies, namelysignificance of location as a factor for selecting a bank keeping a company's transactional account will decrease over time due to development of electronic services. In the studied period, the percentage of indications of convenient location as the most important factor in choosing a bank decreased from $29 \%$ to $16 \%$. The percentage of entrepreneurs indicating location as the most important selection factor decreased on average by $1.4 \mathrm{pp}$ annually (65\% of the index's variability explains the statistically significant model). The percentage of entrepreneurs declaring that a convenient location was one of the three most important factors in choosing a bank dropped from $55 \%$ to $36 \%$. The percentage indicating the location among the 3 key factors of bank selection decreased on average by $2.25 \mathrm{pp}$ annually ( $86 \%$ of the index's variability explains the statistically significant model).

The second hypothesis $(\mathrm{H} 2)$, suggesting that in conditions of better access to information, the significance of fees and commissions when selecting a bank will be higher, has been confirmed only in part. Price parameters became the most important factor of bank selection in the SME sector already in 2008, and the percentage of entrepreneurs' indications of fees and commissions as the most important factor of bank selection increased in the analyzed period from $28 \%$ to $36 \%$, but the changes did not occur linearly. The model turned out to be statistically insignificant and characterized by a relatively low fit, which was mainly due to the results of the survey in 2010, when the greatest increase in the importance of price parameters was noted. It was a time of economic slowdown and rising unemployment in Poland. At that time, companies were looking for all possible savings, and they paid more attention on the costs of banking services. An increase in the importance of fees and commissions when selecting a bank (on average by more than 1.1 pp yearby-year) can also be observed in the combined analysis of three key selection factors. The model was statistically significant at a materiality level of 0.1 , but had a rather low fit (due to the results of 2010).

The assumption (in accordance with $\mathrm{H} 3$ ) that the location of a branch as a bank selection criterion will be most important in the sector of micro enterprises has been confirmed in empirical research. The microenterprises segment recorded the highest percentage of indications (from $15 \%$ to $30 \%$ ) for convenient location as the most important factor in choosing a bank. The lowest 
number of indications of the key role of location was recorded most often in the segment of medium-sized enterprises (from $7 \%$ to 16\%). Apart from 2012, in all the analyzed years the significance of location for micro businesses was statistically significantly higher than for small and medium enterprises. In the entire period under study, micro enterprises pointed to location as the most important factor in choosing a bank, on average $50 \%$ more often than other companies. Focusing on the location in the micro enterprises segment is related to the functioning of these entities, where the owner personally handles most business matters, including the use of banking services. The loss of time, associated with the owner's overcoming the distance in the traditional space, is reflected directly in the loss of income and deterioration of financial indicators. This means that virtual space provides the most benefits in the segment of the smallest and weakest entities, i.e. in the segment of micro enterprises.

Another hypothesis ( $\mathrm{H} 4)$ suggested that virtual space will be used first of all to distribute less complex banking services. The research has confirmed this assumption, the average year-by-year increase in Internet (virtual) transactions was most visible in basic operations, such as viewing balances and making transfers, which grew by $4.5 \mathrm{pp}$ to almost $90 \%$ in 2015 . Trend models are statistically significant and they reflect the course of change well. In the case of more complex products, such as deposits or loans, traditional banking branches were preferred. This can be explained by the need for advice from bank staff.

In contrast to the results of the American research, in Poland there was no impact of the distance between the company and the bank branch on the loan utilization rates and the loan refusal rates. The hypotheses of $\mathrm{H} 5$ and $\mathrm{H} 6$ have not been confirmed. The dependence turned out very weak (V-Kramer coefficient of 0.12) and completely non-linear; enterprises located at a largest and medium distance from the bank facility used the loans more often than those located closest to the banks. This may be due to the higher density of the branch network and other credit procedures. In Poland, these procedures are centralized and only reporting data and scoring systems are used to assess creditworthiness. Informal, local information is not taken into account.

The results of the survey indicate that the emergence of virtual banking space has improved SME access to banking services and thus increased spatial justice. This is especially true for simple operations. For more complex financial services, including granting credits or opening deposits, the spatial proximity of branches still plays a significant role in Poland.

Research results suggest that in the future, a further weakening of the importance of the traditional distribution network of banking services can be expected. Until now, personal contacts and advisory services have been of great importance to traditional branches. However, with the technological development, new tools for individualization of banking services and provision of banking services (e.g. virtual chat rooms, developed call centers) have appeared. A new revolution in service delivery is expected with the spread of video conferencing technology. No personal meetings of entrepreneurs with bank advisors will be needed. High quality advisory services can be provided remotely, without the need to build and maintain an expensive network of banking outlets. Traditional bank branches will lose their importance again, while the virtual space will become a place for providing the vast majority of banking services.

The obtained results may find a number of applications not only in the banking sector (belonging to the group of services of general interest), but also in other areas of the economy, including e-commerce, education services, medical services, central and local government services to citizens and businesses. Virtual space equalizes opportunities, facilitates business operations, and contributes to lower prices and higher quality of offered products and services; making access to products and services fairer. 


\section{References}

Agarwal, S., \& Hauswald, R. (2010). Distance and Private Information in Lending. Review of Financial Studies, 23(7), 2757-2788. https://doi.org/10.1093/rfs/hhq001

Arbore, A., \& Ordanini, A. (2006). Broadband divide among SMEs - The role of size, location and outsourcing strategies. International Small Business Journal, 24(1), 83-99. https://doi. org/10.1177/0266242606059781

Bach, M., Zoroja, J., \& Vukšić V. (2013). Determinants of firms' digital divide: A review of recent research. Procedia Technology, 9, 120-128. https://doi.org/10.1016/j.protcy.2013.12.013

Batorski, D. (2009). Wykluczenie cyfrowe w Polsce. In D., Grodzka (Ed.). Społeczeństwo informacyjne (pp. 223-249). Studia BAS, 3(19). Warsaw: BAS.

Berger, A. N., \& Udell, G. F. (2002). Small Business Credit Availability and Relationship Lending: the Importance of Bank Organizational Structure. Economic Journal, 112(477), F32-F53. https://doi. org/10.1111/1468-0297.00682

Berger, A., \& DeYoung, R. (2006). Technological Progress and the Geographic Expansion of the Banking Industry. Journal of Money, Credit and Banking, 38(6), 1483-1513. https://doi.org/10.17016/ FEDS.2002.31

Boyne, G. M. (1991). Territorial justice: A review of theory and evidence. Political Geography Quarterly, 10(3), 263-281.

Brevoort, K., \& Hannan, T. (2006). Commercial Lending and Distance: Evidence from Community Reinvestment Act Data. Journal of Money, Credit and Banking, 38(8), 1991-2012. https://doi.org/10.2139/ ssrn.593801

CC (2002). The supply of banking services by clearing banks to small and medium-sized enterprises. A report on the supply of banking services by clearing banks to small and medium-sized enterprises within the UK. Competition Commission.

Degryse, H., \& Ongena, S. (2002). Distance, Lending Relationships, and Competition. Journal of Finance, 60, 213-266. https://doi.org/10.1111/j.1540-6261.2005.00729.x

Dell'Ariccia, G. (2001). Asymmetric information and the structure of the banking industry. European Economic Review, 45(10), 1957-1980. https://doi.org/10.1016/S0014-2921(00)00085-4

Deloitte (2018). Digital Banking Maturity Report 2018. Warsaw: Deloitte.

Denton, L., \& Chan. A. K. K. (1991). Bank Selection Criteria of Multiple Bank Users in Hong Kong. International Journal of Bank Marketing, 9(5), 23-34. https://doi.org/10.1108/02652329110007129

Devlin, J. F. (2002). Customer knowledge and choice criteria in retail banking. Journal of Strategic Marketing, 10, 273-290. https://doi.org/10.1080/0965254022000014541

Devlin, J., \& Gerrard, P. (2005). A study of customer choice criteria for multiple bank users. Journal of Retailing and Consumer Services, 12(4), 297-306. https://doi.org/10.1016/j.jretconser.2004.10.004

European Commission (2013). Guide to the application of the European Union rules on state aid, public procurement and the internal market to services of general economic interest, and in particular to social services of general interest. Brussels: European Commission. Retrieved from https://ec.europa.eu/competition/state_aid/overview/new_guide_eu_rules_procurement_en.pdf

Felici, R., \& Pagnini, M. (2008). Distance, Bank Heterogeneity and Entry in Local Banking Markets. Journal of Industrial Economics, 56(3), 500-534.

Forman, C. (2005). The Corporate Digital Divide: Determinants of Internet Adoption. Management Science, 51(4), 641-654. https://doi.org/10.1287/mnsc.1040.0343

Galliano, D., \& Roux, P. (2008). Organisational motives and spatial effects in Internet adoption and intensity of use: evidence from French industrial firms. Annals of Regional Science, 42(2), 425-448. https://doi.org/10.1007/s00168-007-0157-z

Grimes, A., Ren, C., \& Stevens, P. (2012). The need for speed: impacts of internet connectivity on firm productivity. Journal of Productivity Analysis, 37(2), 187-201. https://doi.org/10.1007/s11123-011$0237-z$

Hegerty, S. (2016). Commercial bank locations and 'banking deserts': a statistical analysis of Milwaukee and Buffalo. Annals of Regional Science, 56(1), 253-271. https://doi.org/10.1007/s00168-015-0736-3 
Hinson, R. E., Osarenkhoe, A., \& Okoe, A. F. (2013). Determinants of Bank Selection: A Study of Undergraduate Students in the University of Ghana. Journal of Service Science and Management, 6, 197205. https://doi.org/10.4236/jssm.2013.63021

Katitcioglu, S. T., Tumer, M., \& Kilinc, C. (2011). Bank Selection Criteria in the Banking Industry: An Empirical Investigation from Customers in Romanian Cities. African Journal of Business Management, 5(14), 51-58. https://doi.org/10.5897/AJBM11.408

Kaynak, E., Kucukemiroglu, O., \& Odabasi, Y. (1991). Commercial Bank Selection in Turkey. International Journal of Bank Marketing, 9(4), 30-39. https://doi.org/10.1108/02652329110004249

KNF (2019). Dane miesięczne sektora bankowego - lipiec 2019. Warsaw: Komisja Nadzoru Finansowego. Retrieved from https://www.knf.gov.pl/

Komornicki, T., \& Ciołek, D. (2017). Territorial Capital in Poland. In J., Bradley \& J., Zaucha (Eds.). Territorial Cohesion: A missing link between economic growth and welfare. Lessons from the Baltic Tiger (pp. 93-146). Gdańsk: University of Gdańsk.

Komornicki, T., Zaucha, J., Szejgiec, B., \& Wiśniewski, R. (2015). Powiqzzania eksportowe gospodarki lokalnej w warunkach zmiennej koniunktury - analiza przestrzenna. Warsaw: Institute of Geography and Spatial Organization PAS.

Krishnamurthy, P. (2015). Banking Deregulation, Local Credit Supply, and Small-Business Growth. Journal of Law \& Economics, 58(4), 935-967.

Labrianidis, L., \& Kalogeressis, T. (2006). The digital divide in Europe's rural enterprises. European Planning Studies, 14(1), 23-39. https://doi.org/10.1080/09654310500339109

Leyshon, A., \& Thrift, N. (1996). Financial exclusion and the shifting boundaries of the financial system. Environment and Planning A, 28, 1150-1156. https://doi.org/10.1068/a281150

Leyshon, A., French, S., \& Signoretta, P. (2008). Financial Exclusion and the Geography of Bank and Building Society Branch Closure in Britain. Transactions of the Institute of British Geographers, 33(4), 447-465. https://doi.org/10.1111/j.1475-5661.2008.00323.x

NBP (2008). Development of the financial system in Poland in 2007. Warsaw: National Bank of Poland. Retrieved from https://www.nbp.pl/en/systemfinansowy/fsd_2007.pdf

NBP (2017). Financial System in Poland in 2015. Warsaw: National Bank of Poland. Retrieved from https://www.nbp.pl/en/systemfinansowy/fsd_2015.pdf

PARP (2018). Report on the state of the SMEs sector in Poland. Warsaw: PARP.

Peterson, M. A., \& Rajan, R. G. (2002). Does Distance Still Matter? The Information Revolution in Small Business Lending. Journal of Finance, 57, 2533-2570. https://doi.org/10.1111/1540-6261.00505

Quentin, A., \& Morange, M. (2018). Spatial Justice, Critical Thinking and Normativity in the Social Sciences. Justice spatiale, spatial justice, 7, pp. 22. Retrieved from https://www.jssj.org/wp-content/ uploads/2018/10/JSSJ12_MORANGEQUENTIN_VA.pdf

Rauhut, D. (2017). A Note on Territorial Justice. A paper prepared for the 57th conference of the European Regional Science Association, 29th August - 1st September 2017.

Saleh, M. S., Rosman, M. R. M., \& Nani, N. K. (2013). Bank Selection Criteria in a Customers' Perspective. Journal of Business and Management, 7(6), 15-20.

Sinkula, J. M., \& Lawtor, L. (1988). Bank Characteristics and Customer Bank Choice: How Important are Important Measures. Journal of Professional Services Marketing, 3(3), 133-141. https://doi. org/10.1300/J090v03n03_11

Soja, E. W. (2009). The city and spatial justice. Justice spatiale, spatial justice, 1, pp. 5. Retrieved from https://www.jssj.org/wp-content/uploads/2012/12/JSSJ1-1en4.pdf

Świątek, D., Komornicki, T., \& Siłka, P. (2013). Services of General Interest: Empirical Evidence from Case Studies of the SeGI Project. Europa XXI, 23, 105-130. https://doi.org/10.7163/Eu21.2013.23.6

Ta, H. P., \& Har, K. Y. (2000). A Study of Bank Selection Decisions in Singapore Using the Analytical Hierarchy Process. International Journal of Bank Marketing, 18(4), 170-180. https://doi. org/10.1108/02652320010349058

Talen, E., \& Anselin, L. (1998). Assessing spatial equity: an evaluation of measures of accessibility to public playgrounds. Environment and Planning A, 30, 595-613. https://doi.org/10.1068/a300595

Tumbull, P. W., \& Gibbs, M. L. (1989). The Selection of Banks and Banking Services - Among Corporate Customers in South Africa. International Journal of Bank Marketing, 7(5), 36-39. https://doi. org/10.1108/02652328910134662 
Xue, M., Lorin, M. H., \& Pei-yu, Ch. (2011). Determinants and Outcomes of Internet Banking Adoption. Management Science, 57(2), 291-307. https://doi.org/10.1287/mnsc.1100.1187

Zaucha, J., Brodzicki, T., Ciołek, D., Komornicki, T., Mogiła, Z., Szlachta, J., \& Zaleski, J. (2015). Terytorialny wymiar wzrostu i rozwoju. Spójność, potencjały i użyteczność. Warsaw: Difin.

Zineldin, M. (1995). Bank-company interactions and relationships: some empirical evidence. International Journal of Bank Marketing, 13(2), 30-40. https://doi.org/10.1108/02652329510078677

Zineldin, M. (1996). Bank-corporate client 'partnership' relationship: benefits and life cycle. International Journal of Bank Marketing, 14(3), 14-22. https://doi.org/10.1108/02652329610113135 